\title{
Extensive use of Motorcycles in Karachi, Pakistan: Revisiting the Policies that led us here
}

\author{
Syeda Amena ${ }^{a}$, Syed Fazal Abbas Baqueri ${ }^{b} *$ \\ ${ }^{a}$ Graduate Student Transportation Sciences, UHasselt- Hasselt University, Diepenbeek, Belgium, 3590 \\ ${ }^{b}$ Assistant Professor, Department of Civil Engineering, DHA Suffa University, Karachi, Pakistan, 75950
}

\begin{abstract}
Motorcycles is a dominant transport model in many Asian Cities. Similar is the case with Karachi, where motorcycles constitutes approximately $52 \%$ of the overall passenger transport. Although a motorcycle provides temporary relief in terms of low fuel price, ownership of a vehicle and on top of all an easy commuting option to its owners, it has adversely affected the whole (transportation) system including its users. This paper analyzes various governmental policies that led to the enormous increase in motorcycles and its effects on street crime, Traffic Violation and Traffic Congestion. User attitudes towards opting motorcycles, public transport and environment are also discussed in this paper whill shall be helpful in conducting future studies in this regard.
\end{abstract}

Keywords: Motorcycle, Government Policies, Karachi, BRT

\section{Background}

Motorcycles are widely common in Asian cities because of its flexibility (the opportunity to use public roads in freestyle), affordability and ability to quickly maneuver in a congested road environment. This is the reason the top three largest motorcycle markets in the world are China, India and Indonesia [1-4]. Karachi is a no different case. Motorcycle ownership in Karachi city is increasing day by day because of its easy purchase and low operating cost. Individuals having a low income can also easily own a motorcycle. This has not only resulted in traffic congestion, street crimes and road traffic accidents in the city but has also made the traffic management a burdensome task.

Since their introduction in 1970 , the motorcycle has been the first-choice of most individuals belonging to the middle and low-income group. Today, motorcycles have around 52\% share of motorized transport in the city [5]. This increased ownership and easy-availability of motorcycles may be taken as a positive sign for the motorcycle industry. However, on the other hand, these statistics are not appealing for the city planners and to those who monitor the city infrastructure closely. There is a lack of a basic traffic management system, road infrastructure and a road sense in motorcyclists. For instance, there are no separate lanes for motorcycles, neither motorcycle riders follow the traffic lane-system thus creating a major traffic disruption and a major cause of road accidents as motorcycle riders are involved in around $70 \%$ of the road accidents. In terms of the road infrastructure development, only flyovers and underpasses have been built which, although, helped in doing away with traffic signals, resulted in an increase in traffic flow. The extensive use of motorcycles also results in many individual-level problems for both riders and non-riders. For instance, international research indicates that motorcyclists are subjected to numerous health-related problems [6]. Similarly, motorcycles are involved in the majority of road crashes and it is also one of the major reason behind worrying law and order situation of the city [7]. Despite being aware of these problems, the number of motorcycles has been continuously increasing which indicates that there are other benefits associated with this mode of transport. Besides, there are numerous governmental policies that individually and collectively added made motorcycle an attractive transport mode such as not investing in an effective public transport system. Therefore, the first and the foremost task is to identify the factors that, over the passage of time, increasingly prompted commuters to use motorcycles as their main transport mode. Only then, one can argue how this mode choice behavior can be changed.

With this premise, the focus of this research is to examine why motorcycle usage has increased and what problems are created due to its extensive use? This research answers the following research questions:

- What government policies contributed for an increase in motorcycles?

- Is there an increase in crime rate, traffic violation, congestion and health-related issues due to extensive use of motorcycles?

${ }^{*}$ Corresponding author. Tel.: + 92-21-35244851 (Ext. 317)

Fax: +9876543210; E-mail: fazal.abbas@sdsu.edu.pk

(c) 2019 International Association for Sharing Knowledge and Sustainability.

DOI: $10.5383 /$ JTTM.01.02.003 
- Despite high vulnerability, why commuters have switched to this mode of transport?

These have been answered through a detailed overview of various government policies and their effect on motorcycle usage. Furthermore, Effect on crime rate, traffic violations and traffic congestion due to extensive use of motorcycles has also been discussed. The next section of this paper mentions a few details about Karachi followed by the discussion on governmental policies.

\section{About Karachi City}

Karachi is the largest cosmopolitan city of Pakistan and eighth populous metropolitan city in the world with an estimated population of above 24 million [8]. It is in the South of Pakistan which connects two largest seaports of Pakistan Port Qasim and Kimari with the rest of the country. The city generates and controls most of the country's economic happenings. It serves as the economic hub of the country and generates leading employment opportunities. Therefore, people from all over the country migrate to Karachi especially from the nearby cities and villages of Sindh province.

At present, the only operational mode for passenger transport is via the road network. In the past, there used to be ferry service through Lyari River however due to continuous contamination of the river it cannot be used as a medium of transport anymore. Furthermore, Karachi Circular Railway (KCR) - an inter-city railway service which used to connect the areas where over $45 \%$ of the jobs are located, is no more operational [9]. Thus, the unavailability of some alternative and less attractiveness of the others, involuntarily made motorcycles as a favorable transport mode. This research aims to identify the factors that triggered the strong usage of motorcycles and how this behavior can be changed. Some of the relevant background aspects are explained below.

Karachi has a vast road network of around $10,000 \mathrm{~km}^{2}$ that is spread across the city [10]. This consists of Local, Collector and Arterial roads (Fig 1). However, this network is inadequate to meet the present needs of transportation and with the increasing number of vehicles every day especially motorcycles, it can be expected to be worse. The Household Travel Survey of Karachi conducted by Japan International Cooperation Agency (JICA) estimates approximately 24.2 million trips on daily basis [5]. Majority consider it due to the lack of political will and differences between the provincial and the federal government.

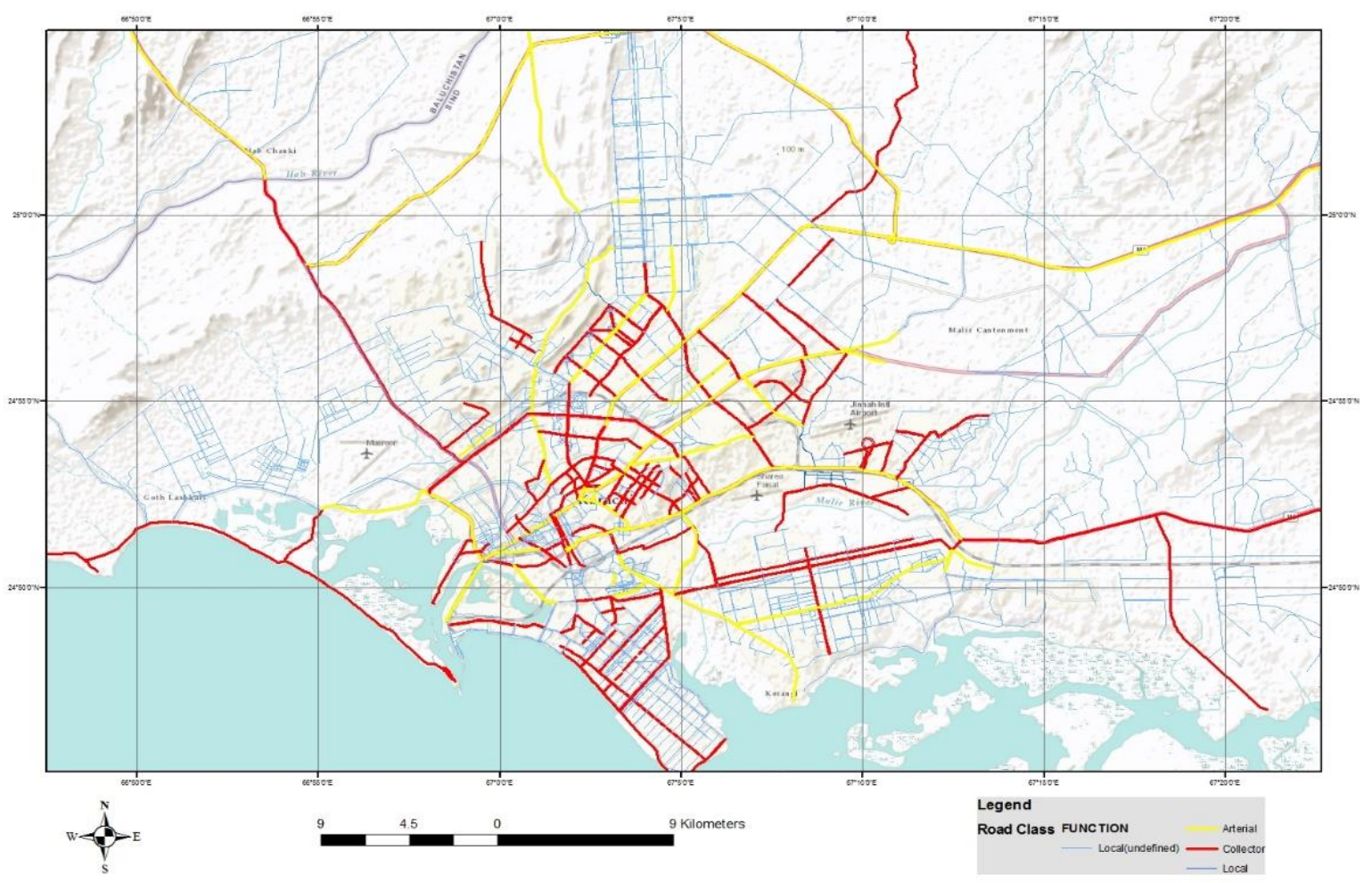

Fig 1: Road network of Karachi City

\subsection{Current Transport Status}

Today, commuting in Karachi city has gradually become more and more cumbersome. The metropolis still awaits its first BRT to be operational with the project facing delays since the last couple of years. Similarly, homogenous fares for para-transit such as three-wheeler (rickshaw) is a thing of the past due to its high demand. Now, most of the times the rate is often settled on the whim of the driver. Thus, those who do not own a vehicle ends up in spending a major share of their monthly income on transport. A new motorcycle is priced around Rs. 45,000 (around 400 euro) and has much lower fuel consumption than cars or public transport fare. Furthermore, an increase in the local production of motorcycles also decreased its capital cost which made it further attractive. Moreover, motorcycles can also be purchased on instalments with a mere down payment of Rs. 5,000 (45 euro). Therefore, in the present circumstances, motorcycle ownership seems to be a very attractive alternative. 


\subsection{Degrading Public Transport System}

A study conducted by Urban Design Research Cell of the NED University at different bus-stops revealed interesting results related to public transport users [11]. $70 \%$ of the surveyed males agreed that they would like to purchase a motorcycle but do not have the means, because the monthly travel cost of travelling via motorcycle is less than half of that of public transport. Another $20 \%$ of them mentioned family restrictions as the reason for not using a motorcycle; some household considers it as an unsafe mode and does not use it. Females usually do not ride motorcycles in Pakistan due to the culture here. However, $53 \%$ of female respondents agreed to ride a motorcycle if given an option. Majority agreed that using a motorcycle reduces the commuting time to less than $50 \%$ as compared to using a bus.

Due to the limited public transport infrastructure (buses, lines) there is a devastating ratio of 1:34 passenger per seat [5]. Thus, those who can afford other means of transport avoid using public transport.

\subsection{Motorcycle as an attractive transport mode}

In the present circumstances, the cheapest option available to travel is via motorcycles. Those who can afford it, purchase it to avoid the hassle of travelling via public transport. There were 450,000 registered motorcycles in 1990 (Fig 2) which increased to 500,000 in 2000, above 1 million in 2010 [11] and in 2012 about 1.5 million [12]. At present it is estimated that 700 new motorcycles hit the road on a daily basis which was around 340, 10 years ago, thus, raising the total figure to 2.7 million with an increase of $230 \%$ in last decade or so [13]. Earlier, it was estimated that there will be 3.64 million motorcycles in 2030 [11]. However, based on the exponential increase in motorcycle ownership rate, degrading public transport system and the dilapidated road network, this assessment can be safely termed as underestimation of motorcycles ownership. Motorcycles constituted 52\% of the transport system in 2011 [5] and taking into account the increasing rate of ownership it must be around 60\% now.

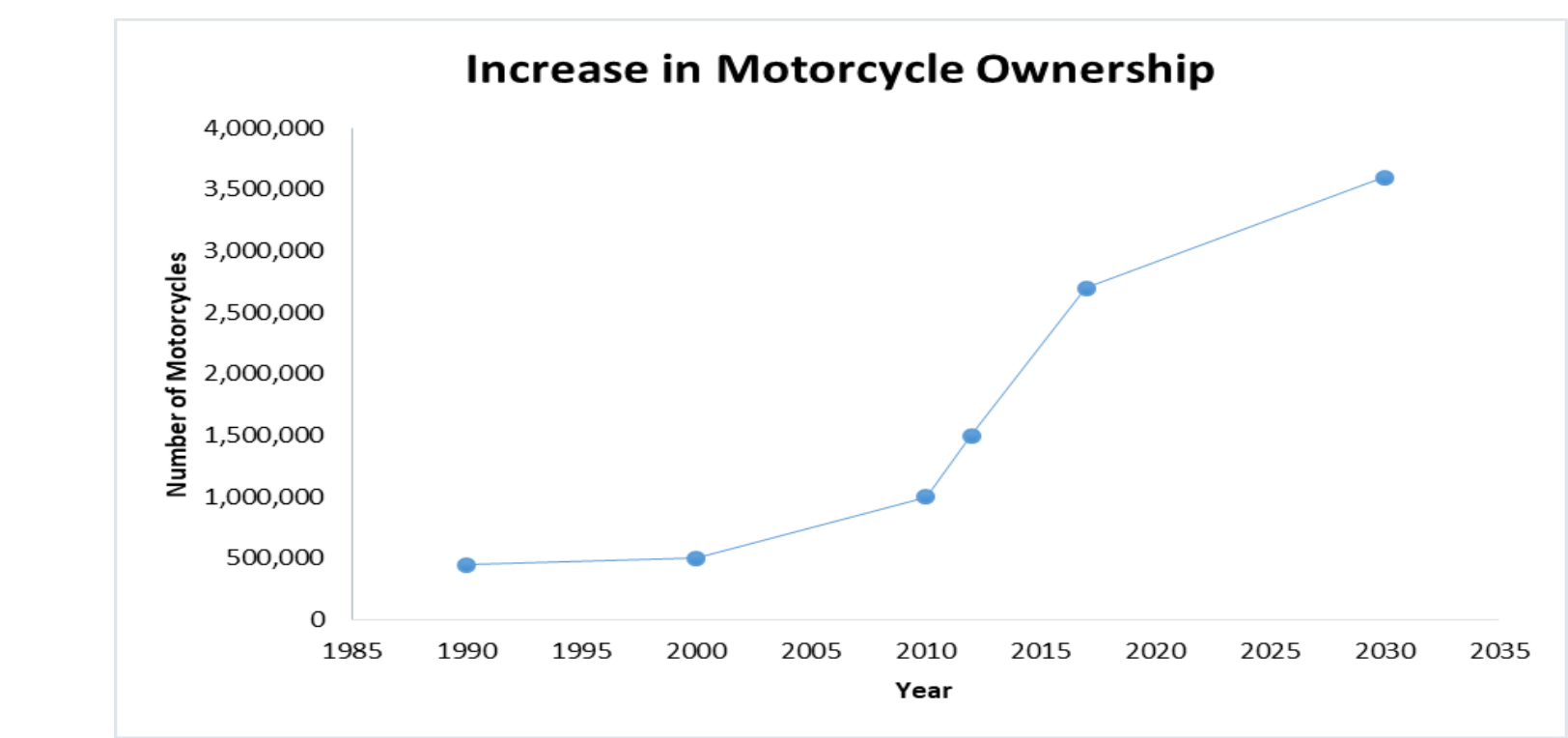

Fig 2: Motorcycle ownership in Karachi city

\section{What government policies contributed for an increase in motorcycles?}

There are numerous examples where government policies to control the rapid growth of motorcycles back-fired. Hence, despite a few time-to-time policies created to discourage the use of motorcycles, the latter remains the most common transport mode for karachiites. Few notable policies amongst them are further discussed.

\subsection{Ban on Pillion-riding}

Pillion-riding is considered dangerous as sometimes more than two persons are sitting behind the driver. To discourage pillion riding, long pillion-riding bans (a ban of 1 week after every two weeks) were introduced from time to time. However, this motivated most of the pillion-riders belonging to the lowincome class to purchase their own vehicle which resulted in a further increase in motorcycle ownership in the long run [14].
This policy has been introduced from time to time especially during the prime shopping seasons.

\subsection{Building Flyovers and Underpasses}

The new local government system (1999 - 2008) invested heavily in infrastructure projects by building flyovers and underpasses, remodelled intersections and revamped roads. Furthermore, two by-passes to cater to an increased freight transport and another expressway to accommodate increased traffic was constructed during this time period [10]. However, there was no investment in improving the state of the public transport system. Together, both resulted in increased motorcycle ownership as the most attractive alternative.

\subsection{Informal Transport Options Such as QINQUI}

Another aspect where policy lacks attention are the informal transport options which are not regulated. The most interesting example of the informal transport is Qinqui service. Qinqui has a 6-seater steel body attached to the back of a motorcycle. It has a seating capacity of 6 persons plus two more passengers 
can sit on the main body of the motorcycle behind the driver (like pillion-passenger). Qinqui had many advantages over public transport such as a low operating cost and fixed seat for every passenger thus making it more attractive than buses. Qinqui started running on fixed routes. To join a route, one just needs to own the vehicle (Qinqui) and pay a small amount of operating charges on a daily basis. The annual turnover of QINGQI activity is Rs 8.64 billion and as such it adds substantially to Karachi economy [15]. It was first introduced in Karachi in 2002 and reached its peak in 2011. However, due to the government crackdown against Qinqui these services ultimately came to an end. After the ban, the owners started selling the motorcycles at cheap prices.

These informal transports have their own association that aim to regulate and negotiate their demands with the government and police officials. In the case of Qinqui, the association managed the routes to avoid overlapping and register its drivers. It also negotiated with the government, the possibility of separate lanes for Qinqui but the Traffic Police Officials were not interested particularly because of its safety issue. A similar association also exists for public transport operators and some suggest it to be behind the prolonged delay of BRT service in the city.

\subsection{Compressed Natural Gas Crisis}

Compressed Natural Gas (CNG) was introduced by the Government of Pakistan in 1990 as a cheap alternative to petrol and diesel. It helped in reducing foreign spending as well as air pollution. Most of the car owners, public transport operators and university and school bus operators installed CNG kits as it was much cheaper (Rs 7 per unit cost) as compared to Diesel (Rs 40 per unit cost). However, things changed when the oil crisis occurred between 2008 and 2010 [15]. During this time, the oil price and power outrage shortages increased substantially, therefore many people installed gas generators in households, industries and shops. Subjected to this high demand, today, there is a shortage of CNG in the country and Karachi being the industrial hub suffers the most. The CNG supply is now limited to only 4 days per week which results in a long waiting line of vehicles at CNG stations. In CNG-off days majority of the buses do not operate and para-transit owners charge a hefty amount. This makes motorcycle ownership a further attractive alternative as motorcycles operate on petrol with a lower operating cost than these.

\subsection{Vehicle Import Taxes}

Considering the heavy dependency of commuters on motorcycles, 'green' motorcycles can also be an attractive option. It shall not only reduce air pollution but also minimize the vehicle operating cost. Furthermore, Chinese-manufactured green bikes are cheaper than the local motorcycles produced in the country. However, there is a heavy duty imposed on imported vehicles and motorcycles are no different case. The heavy import cost and other taxes make green motorcycles twice as expensive as their original cost [11].

\subsection{Inadequate Car Parking Spaces}

There is an absenteeism of adequate parking by-laws in the city to ensure that every building should have its required parking spaces. Finding a car parking in the city centre can be hectic during peak-hours and weekends. Similarly, there are also not enough parking spaces for motorcycles. However, it is relatively easier to park a motorcycle as most of the times these are parked on the left-most lanes of the road. This, on the other hand, reduces road capacity and creates hurdle in the traffic flow.

\subsection{Online Taxi}

The high-penetration of mobile technology triggered many carsharing services around the world and Pakistan is a no different case, especially its major cities. Two of the major online taxi services, Uber and Careem, are fully operational in Karachi since 2016. However, as it is said, 'need is the mother of invention'; the concept of bike-taxi was introduced by Bykea which was later also incorporated by many car-sharing platforms as well. Bykea's punch-line further clarifies the above-mentioned things:

"WE operate in geographies where there are more motorcycles than cars" [16].

Simply put, the degrading condition of public transport: the absence of a Mass Transit System and the subtraction of urban rail network which was previously functional also led to motorcycles being the prime transport mode for many commuters.

On this premise, experts term the city traffic as a Planned Chaos; 20 million people leave their homes on daily basis to perform their daily tasks and come back to their homes without a proper traffic management system.

\subsection{Tracking devices compulsory for all motorcycles}

A forthcoming policy proposed by the Sindh government is to make tracking devices compulsory for all motorcycles [17]. This policy mainly aims to control motorcycle-related crimes (further explained in section 4), 6monitor motorcycle usage and regulate motorcycle taxes on its vehicle miles travelled. However, without a strict check and balance, this may not be an effective measure to manage motorcycles. Similarly, as can be seen by the official's statement, one of the major focus of this policy is to create a business opportunity rather than solving the core issue [17]. This policy is expected to be implemented this year.

\subsection{Bus Rapid Transit: Phase 1}

The first BRT (Green Line) shall be operational in 2021. There are a total of six main BRT lines. The feeder lines are planned for the second phase after completion of the main lines. In the absence of an adequate feeder system, the ridership shall be low especially in terms of attracting motorcycle users [3]. Therefore, a major shift from motorcycles should not be expected in the first phase of BRT operation.

\section{Effect on crime rate, traffic violations and traffic congestion due to extensive use of motorcycles?}

Street crimes have been very common in Karachi before 2015 which, however, has been controlled to some (major) extent after successful conduction of the Karachi Operation. According to the Citizens Police Liaison Committee (CPLC) statistics for 2016, the number of violent crimes (murder, kidnapping) reported has decreased from 2015. However, small street crime rose by $38 \%$ and motorcycle thefts were also $24 \%$ higher than in prior years [18]. Burglars and mobile snatchers usually prefer motorcycles for conducting crimes for many reasons. These are explained below: 
1. Motorcycles provide one the ability to conduct the crime and escape immediately from the crime scene as compared to any other vehicle. Besides, it is found that street crimes are mostly conducted in traffic jams as motorcycles can penetrate easily between two cars. Furthermore, in case of traffic jams, a motorcycle can manoeuvre faster as compared to cars.

2. The use of a helmet is very rare among motorcyclists; however, burglars always wear it as it reduces the chance of being caught by any CCTV footage. Additionally, it decreases the likelihood of being caught by traffic police during their campaigns against individuals not wearing a helmet.

3. The availability of a stolen motorcycle increases crime ratio, as in most cases of street crime, a stolen motorcycle is found to have been used for theft. Moreover, the identification of the original chassis number, the only criteria to distinguish if the vehicle is stolen or not, needs a trained eye and cannot be detected by a cop during a shallow road-side inspection [19]. Therefore, burglars use stolen motorcycles to conduct or escape from a crime scene. Many high-profile killings in the city during recent years involved the use of motorcyclists by killers.

Due to the high demand for motorcycles, vehicular theft is also very common. Furthermore, shortage of motorcycle parking spaces across the city makes its theft easier as the motorcycles are not properly parked. Police have identified over 60 motorcycle theft spots in 2015 [20]. This is now considered as a billion rupee industry throughout the country [19]. A stolen motorcycle is available at less than the half of its actual market price. A common man cannot recognize and is neither interested to check if the motorcycle which he is about to purchase second-hand is stolen or not.

To counter the high rate of street crime, motorcyclists are subjected to intensive snap-checking as in most cases of roadside mobile snatchings and targeted killing the burglars use motorcycles (explained later as well). There were numerous goals behind introducing this policy. For example, it encouraged motorcyclists to have proper documentation of motorcycles particularly before purchasing a second-hand vehicle. Furthermore, it also discouraged extensive use of motorcycles as the possibility of being snap-checked was high which should result in some time loss. However, due to weak enforcement plans and dishonesty among some ranks within the police officials, the desired results were not attained. This policy has been implemented from time to time especially when the crime reports are increased.

\subsection{Traffic Violation and Traffic Congestion}

A major cause of these road accidents is wrong-way driving. Similarly, motorcyclists also violate parking laws by parking motorcycles anywhere possible. There are no by-laws to define a minimum required parking spaces for any building based on its trip attraction. Therefore, anti-lifting trucks are frequently seen removing wrongly parked motorcycles from in front of major shopping centres. These (double) parking also reduces the capacity of the roads as some lanes are reserved for parking purpose. Most of the time traffic violation results in traffic congestion. These violations can be wrong way movement alongside the highway to save travelling extra mile for a Uturn. Risky driving is also very common among young motorcyclists.

\section{Why commuters are using motorcycle despite high vulnerability?}

Motorcyclists are undoubtedly most vulnerable motorized transport users with involvement in around $68-72 \%$ [21] of the total road accidents in the city (Fig 3). Amongst the 30,274 road accidents which occurred in 2016, approximately 25,855 involved at least one motorcyclist which constitutes around $70 \%$ of total accidents. This figure is only based on the victims that came to hospitals for recovery. Thus, there is a high possibility of underreporting especially for minor crashes. Despite being aware of these alarming figures, there has been an increase in motorcycle ownership in the city. Therefore, it is important to study why motorcycles are the most preferred mode of transport even with the high vulnerability associated with it. This question was addressed by asking respondents 15 preference-based questions (Table 1) which are divided into four main types: Pro Driving attitude, Public transport, Motorcycle Sharing and Environmental concern. The data was collected through a questionnaire-based survey from 300 respondents through social media.

Table 2: Preference Questions related to Driving Attitude, Public transport, motorcycle sharing and environment

\begin{tabular}{|c|c|}
\hline Questions & Domain \\
\hline $\begin{array}{l}\text { Q1. I prefer not to have the responsibility } \\
\text { of driving } \\
\text { Q2. I feel safer driving myself rather than } \\
\text { others driving me } \\
\text { Q3. I enjoy driving } \\
\text { Q4. I feel nervous when driving }\end{array}$ & $\begin{array}{l}\text { Pro Driving } \\
\text { Attitude }\end{array}$ \\
\hline $\begin{array}{l}\text { Q5. It makes me uncomfortable to ride on } \\
\text { public transport } \\
\text { Q6. I feel safe taking public transport } \\
\text { Q7. I believe that people use public } \\
\text { transport when they do not have any } \\
\text { other choice }\end{array}$ & Public Transport \\
\hline $\begin{array}{l}\text { Q8. I am very excited to use motorcycle } \\
\text { sharing } \\
\text { Q9. I would like to use motorcycle sharing } \\
\text { service only if it reduces travel time } \\
\text { Q10. I would like to use motorcycle sharing } \\
\text { service only if it reduces travel cost } \\
\text { Q11. I found motorcycle sharing as more } \\
\text { convenient compared to having a } \\
\text { motorcycle of my own. } \\
\text { Q12. Motorcycle sharing have potential to } \\
\text { reduce crimes that are usually carried } \\
\text { out using a motorcycle (e.g. snatching, } \\
\text { motorcycle theft etc.) } \\
\text { Q13. Motorcycle sharing have potential to } \\
\text { reduce parking problems in the city }\end{array}$ & $\begin{array}{l}\text { Motorcycle } \\
\text { Sharing }\end{array}$ \\
\hline $\begin{array}{l}\text { Q14. I am concerned about global warming } \\
\text { Q15. I am willing to spend a bit more to } \\
\text { buy an environmentally friendly } \\
\text { product }\end{array}$ & $\begin{array}{l}\text { Environmental } \\
\text { Concern }\end{array}$ \\
\hline
\end{tabular}

Fig 4 shows respondents attitude towards motorcycle, public transport and the environment. $60 \%$ of the respondents disagree with the statement "I prefer not to have the 
responsibility of driving". Moreover, $60 \%$ of the respondents agree with the statement "I feel safer driving myself rather than others driving me". Only $10 \%$ of the respondents quoted that they don't enjoy driving. Similarly, most of the respondents overruled that the statement that they "feel nervous when driving". Therefore, to summarize, it can be easily stated that most of the respondents' show are pro-driving behavior. $15 \%$ of the respondents disagree with the statement "it makes me uncomfortable to ride on public transport" while $80 \%$ of respondents agree with the statement "I believe that people use public transport when they do not have any other choice".

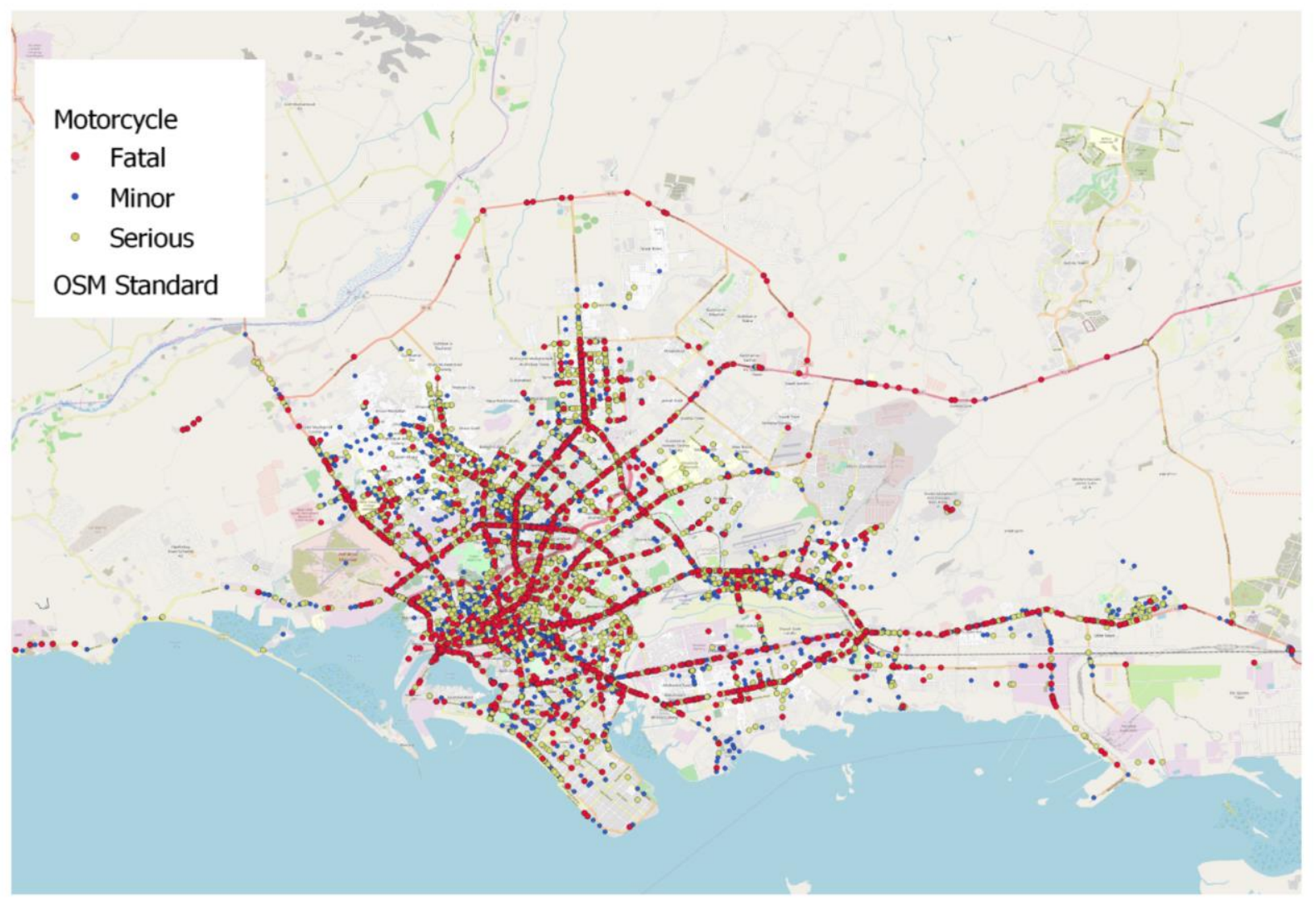

Fig 33: Road Traffic Accidents involving Motorcyclists

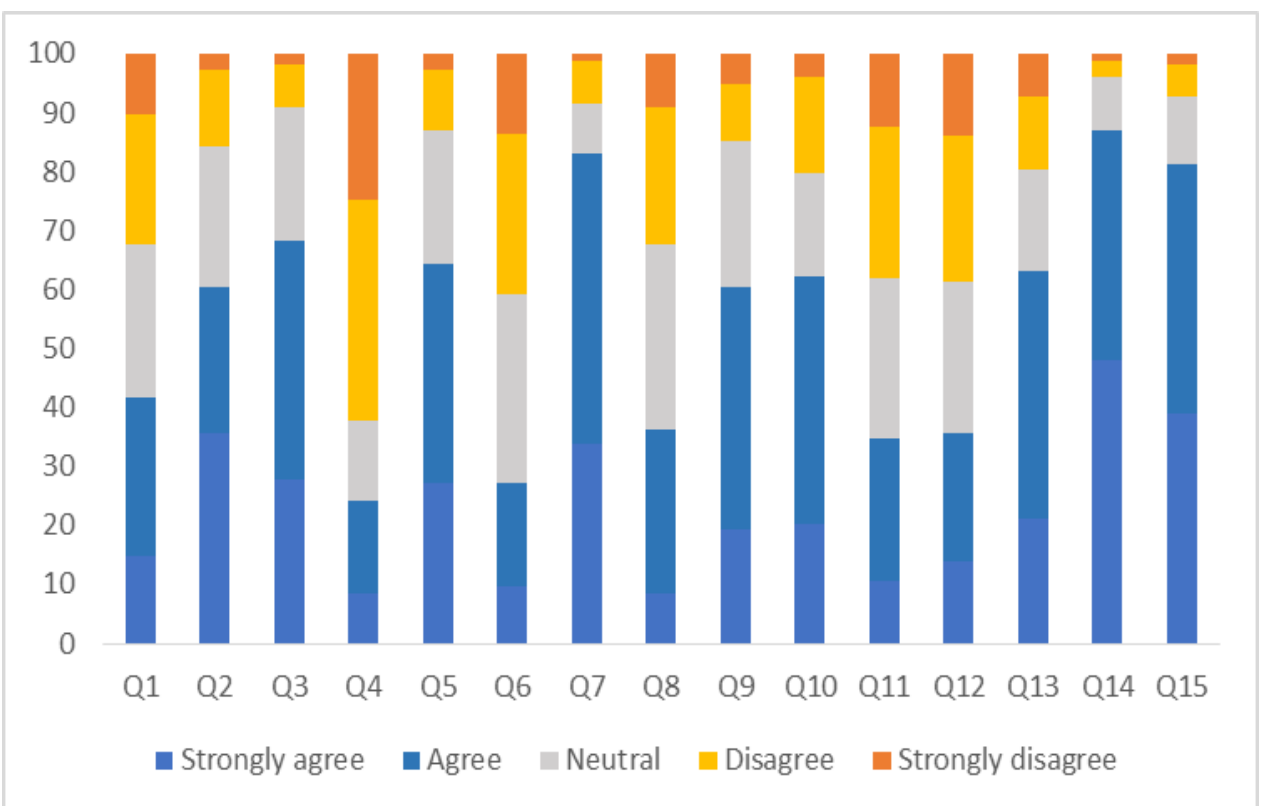

Fig 44: Results of the questions related to Pro-deriving behavior 


\section{Way Forward}

To summarize, there are numerous government policies that led to an increase in motorcycles in Karachi city. Furthermore, the present state of the public transport is very bad and most of the commuters consider it as very last option especially those who cannot own a motorcycle. Individuals consider motorcycle as a convenient transport mode however, the availability of a better transport system has the potential to shift motorcyclists. The availability of a better Mass Transit System shall take into account the current preferences of the users to encourage mode shift from motorcycles.

\section{References}

[1] Leong, L. V., and A. F. Mohd. Sadullah. A Study on the Motorcycle Ownership : A Case Study in Penang State Malaysia. Journal of the Eastern Asia Society for Transportation Studies, Vol. 7, No. 2004, 2007, pp. 528 539.

[2] Susilo, Y. O., T. B. Joewono, and U. Vandebona. Reasons Underlying Behaviour of Motorcyclists Disregarding Traffic Regulations in Urban Areas of Indonesia. Accident Analysis and Prevention, Vol. 75, 2015, pp. 272-284. https://doi.org/10.1016/j.aap.2014.12.016.

[3] Hoang, L. Q., and T. Okamura. Influences of Motorcycle Use on Travel Intentions in Developing Countries: A Case of Ho Chi Minh City. Journal of Eastern Society for Transportation Studies, Vol. 11, 2015.

[4] Nguyen, L. X., and T. M. Nguyen. Analysis of Motorcycle Ownership: A Case Study in Ho Chi Minh City. 2017.

[5] Japan International Cooperation Agency. Karachi Transportation Improvement Project (KTIP) - 2030. 2012.

[6] Shivakumara, B., and V. Sridhar. Study of Vibration and Its Effect on Health of the Motorcycle Rider. Online Journal of Health and Allied Sciences, Vol. 9, No. 2, 2010. https://doi.org/10.4273/ijvss.2.2.05

[7] Arshad Dogar, S. R. Disturbing Data on Motorcycle Accidents. the News Sunday. http://tns.thenews.com.pk/disturbing-data-motorcycleaccidents-in-lahore-and-karachi/\#.WjrOjrenE_5. Accessed Dec. 10, 2017.

[8] Express Tribune. Population Explosion: Put an Embargo on Industrialisation in Karachi. https://tribune.com.pk/story/614409/populationexplosion-put-an-embargo-on-industrialisation-inkarachi.
[9] Hasan, A. KCR Concerns. Dawn, Feb 05, 2017.

[10] Hussain. In Karachi, 16,562 More Vehicles Hit the Roads Each Month. Pakistan Today2. https://www.pakistantoday.com.pk/2011/12/24/inkarachi-16562-more-vehicles-hit-the-roads-each-month/. Accessed Dec. 23, 2017.

[11] Hasan, A. Motorbike Transit. Arif Hasan. http://arifhasan.org/articles/motorbike-transit. Accessed Dec. 23, 2017.

[12] Web Desk. 99\% of Motorcycles in Karachi Are Unregistered: Sindh AG. The Express Tribune. https://tribune.com.pk/story/466733/99-of-motorcyclesin-karachi-are-unregistered-sindh-ag/. Accessed Dec. 27, 2017.

[13] Ayub, I. 700 New Motorbikes Hit City Roads Every Day, Multiply Traffic Problems. Dawn. https://www.dawn.com/news/1370976. Accessed Dec. 10, 2017.

[14] Alvi, O. Note Book: 'City of Bikes.' Dawn. https://www.dawn.com/news/1370976. Accessed Dec. 10, 2017.

[15] Arif Hasan, M. R. Responding to the Transport Crisis in Karachi. Karachi, 2015.

[16] Bykea. http://www.bykea.com/. Accessed Dec. 8, 2017.

[17] Ali, I. Sindh Govt to Make Tracking Devices Compulsory for All Motorcycles. Dawn. https://www.dawn.com/news/1372179. Accessed Dec. 20, 2017.

[18] Ali, I. Bank Heists, Motorbike Thefts Increase in Karachi despite Operation, Police Data Shows. Dawn. https://www.dawn.com/news/1275476. Accessed Dec. 12, 2017.

[19] Siddiqi, A. B. Karachi's Criminal Enterprises: Cogs in the Wheel. Dawn. https://www.dawn.com/news/1172207. Accessed Dec. 10, 2017.

[20] Ayub, I. Over 60 Motorbike Theft Spots Identified across City. Dawn. https://www.dawn.com/news/1181389. Accessed Dec. 15, 2017.

[21] Road Traffic Injury Research \& Prevention Centre. Road Traffic Injury Research \& Prevention Centre Yearly Report. 2011. 